The results of this investigation suggest that the use of betamethasone disodium phosphate in the treatment of oral ulcers is commonly associated with adrenal suppression; administration of this steroid in oral lesions cannot therefore be justified any more. Indeed, topical oral betamethasone disodium phosphate is no longer available in this country. However, therapeutic doses of topical hydrocortisone hemisuccinate and betamethasone 17-valerate do not impair adrenal function in adults. Their efficacy in the treatment of recurrent aphthous ulceration (Cooke and Armitage, 1960) and oral lichen planus (Cawson, 1968) has been established. It should be borne in mind that, while minor aphthous ulcers are often trivial and do not always require treatment, patients with major aphthous ulcers (Lehner, 1968) require constant attention and topical steroids cannot be withheld. Evidence in favour of an autoimmune pathogenesis of recurrent aphthous ulcers (Lehner, $1964,1969)$ has rationalized the use of steroids in this condition.

We wish to thank Glaxo Laboratories for their assistance and the medical illustration department for the illustrations. We are grateful to our colleagues who volunteered for some of the tests.

\section{REFERENCES}

Cawson, R. A. (1968). British-Medical fournal, 1, 86.

Cooke, B. E. D., and Armitage, P. (1960). British Medical fournal, 1,
Czarny, D., and Brostoff, J. (1968). Lancet, 2, 188.

El-Shaboury, A. H. M. (1966). MD. Thesis, University of Wales. Quoted by Picton Thomas, 1968, Guide to Steroid Therapy. Quoted by Picton

Friedman, M., Fletcher, J., Hinton, J. M., Lennard-Jones, J. E., Misiewicz, J. J., and Parrish, J. A. (1967). British Medical fournal, Misiewic 335 .

Hicklin, J. A., and Wills, M. R. (1968). Annals of the Rheumatic Diseases, 27, 33

Keczkes, K., Frain-Bell, W., Honeyman, A. L., and Sprunt, G. (1967) British fournal of Dermatology, 79, 475.

Laurence, D. R. (1966). Clinical Pharmacology, 3rd ed. London, Churchill.

Lehner, T. (1964). Lancet, 2, 1154.

Lehner, T. (1968). Proceedings of the Royal Society of Medicine, 61, 19.

Lehner, T. (1969). Archives of Oral Biology, 14, 843.

Lessof, M. H., Lyne, Cynthia, Maisey, M. N., and Sturge, R. A. (1969). Lancet, 1, 642.

McHardy-Young, S., Harris, P. W. R., Lessof, M. H., and Lyne, Cynthia (1967). British Medical fournal, 2, 740.

MacPhee, I. T., Sircus, W., Farmer, E. D., Harkness, R. A., and Cowley, G. C. (1968). British Medical Foumal, 2, 147.

Mattingly, D. (1962). Fournal of Clinical Pathology, $15,374$.

Raffle, E. J., and Frain-Bell, W. (1967). British Fournal of Dermatology, $79,487$.

Scoggins, R. B. (1962). Fournal of Investigative Dermatology, 39, 473. Scoggins, R. B., and Kliman, B. (1965). New England fourmal of Medicine, 273, 831

Truelove, S. C., and Morris-Owen, R. M. (1958). British Medical fournal, 1, 603 .

Wood, J. B., Frankland, A. W., James, V. H. T., and Landon, J. (1965). Lancet, 1, 243.

\title{
Toxoplasma Infection in an Urban Community
}

\author{
J. H. PRICE,* M.B., CH.B., M.R.C.G.P.
}

\begin{abstract}
Summary : A survey was undertaken in an urban com$\checkmark$ munity to examine the intrafamilial epidemiology of toxoplasma infection and its relation to a set of environmental variables. Statistically significant relations were found with (a) ownership of a dog or cat ; (b) the handling of pet food, particularly cat food; and (c) a " risk" score compounded from the handling of pet food and lack of cleanliness in the kitchen.
\end{abstract}

\section{Introduction}

It has been known for several years that toxoplasmosis occurs in adults of 50 years and over, and that the infection, though usually very mild, can be fatal (Kass et al., 1952). Particularly is this true when it is associated with other diseases (Hemsath and Pinkerton, 1956). Glandular toxoplasmosis in people aged 50 and over can give rise to difficult diagnostic problems, as the glands may resemble tuberculous or neoplastic lymph nodes (Beverley and Beattie, 1958 ; British Medical fournal, 1968).

An excellent survey of the possible modes of human infection by Toxoplasma gondii is given by Hutchinson (1967), but most epidemiological and clinical surveys do not specifically deal with older age groups.

The present survey, carried out in an urban general practice and based on the dye test of Sabin and Feldman (1948), is a study of the epidemiology of the disease in this age group.

\section{Materials and Methods}

Sixty European men aged between 51 and 59 years, who visited a general practitioner in his consulting-room during the 12 months April 1967 to March 1968, agreed to have blood

\footnotetext{
- General Practitioner, Birmingham.
}

D taken for the toxoplasma dye test. Records were then searched to find if the patients were married and had wives on the practice list, and, if so, the man and his wife were admitted to the study.

A visit was made to the homes of these husbands and wives and a sample of blood was obtained from the wife also. A health inspector, who was not acquainted with the serological results, visited and completed a questionary. At the same time he assessed the cleanliness of the kitchen and bedroom on a simple three-point scale.

The questions on the form recorded recent and remote contacts with domestic pets (cats, dogs, rabbits, pet mice, and budgerigars), contact with wild mice and rats, the "worming" of pets, flea infestation, details of holidays and service abroad, handling of raw meat for human consumption in the home, handling of pet food, salad eating, and gardening. All these have been suggested as possible factors in the transmission of toxoplasma infection to man. A question concerning the ownership of goldfish was added as a "negative check."

Six of the original 60 men were not married, five had wives who were not on the practice list, two had wives who were in hospital, two wives declined to give samples of blood, one husband and wife moved from the area, and one of the husbands died during the period of investigation. This left 43 households where it was possible to complete the inquiry.

The dye tests based on the technique of Sabin and Feldman (1948) were performed at the Public Health Laboratory at Swansea, the results being added to the form. The findings were transferred to punch cards for analysis and a computer programme was used for statistical evaluation of the results.

Tables were made to compare dye test titres with each of the variables, and analysis of variance was done by the Snedecor test to obtain $F$ values. 


\section{Results}

In order to measure the accuracy of the method of collecting, transporting, and testing blood samples in the study, 13 duplicate tests were performed two to four weeks after the primary test. Three samples positive at 1:4 dilution, five samples at $1: 16$, one at $1: 32$, and three at $1: 64$ remained the same. Only one sample of blood varied, and this decreased from $1: 16$ to $1: 4$ in two weeks.

The full distribution of the primary tests is given in Table I. For practical purposes, however, they were classified in three groups, as follows: (1) those with a titre negative at $1: 4$ dilution, (2) those with a titre positive $1: 4$ to $1: 16$ inclusive, and (3) those with a titre positive $1: 32$ to $1: 128$ inclusive.

TABLE 1.-Distribution of Dye Test Titres

\begin{tabular}{|c|c|c|c|c|c|c|c|}
\hline & \multirow{2}{*}{ Negative } & \multicolumn{6}{|c|}{ Positive } \\
\hline & & $1: 4$ & $1: 8$ & $1: 16$ & $1: 32$ & $1: 64$ & $1: 128$ \\
\hline$\underset{\text { Wives }}{\text { Husbands }}$ & $\begin{array}{l}11 \\
15\end{array}$ & $\begin{array}{l}7 \\
7\end{array}$ & $\begin{array}{l}0 \\
0\end{array}$ & $\begin{array}{l}16 \\
13\end{array}$ & $\frac{1}{3}$ & $\begin{array}{l}7 \\
4\end{array}$ & $\frac{1}{1}$ \\
\hline
\end{tabular}

For the purpose of analysis these three groups have been coded $-1,0$, and +1 . This grouping was found to provide convenient numbers for statistical comparison and it is also diagnostically acceptable. Beverley (1960) attached particular significance to the high titres; he suggests that single specimens of blood giving results positive at $1: 32$ in a clinically normal community are suspicious of infection, 1:64 suggestive, and $1: 128$ likely. This suggestion is confirmed by clinical cases, and two adults with glandular toxoplasmosis proved by gland biopsy and initial dye test titres greater than $1: 1,000$ diagnosed in my practice in the last four years had subsequent titres of $1: 64$ and $1: 16$ respectively after clinical recovery. The dye tests were carried out at the same laboratory at Swansea.

Negative results may also be regarded as reliable, and the possibility of a prozone in the dye tests giving false-negative results of a type reported by Fletcher (1965) was excluded by routine tests at further dilutions. J. C. Siim, of the State Serum Institute, Copenhagen (personal communication), also believes that in a specialized laboratory, such as the one where these tests were carried out, a negative result can be taken as proof of no infection.

Family Concentration.-Table II shows the association between husbands' and wives' titres. There does not appear to be a significant correlation.

TABLE II.-Dye Test Titres in Husbands and Wives

\begin{tabular}{|c|c|c|c|c|}
\hline & & \multicolumn{3}{|c|}{ Dye Test Titres of Wives } \\
\hline & & $\underset{(-1)}{\operatorname{Neg} . ~} 1: 4$ & $\begin{array}{c}\text { Pos. } 1: 4 \text { to } \\
1: 16 \\
(0)\end{array}$ & $\begin{array}{c}\text { Pos. } 1: 32 \text { to } \\
1: 128 \\
(+1)\end{array}$ \\
\hline \multirow{2}{*}{$\begin{array}{l}\text { Dye test } \\
\text { titres of } \\
\text { husbands }\end{array}$} & \multirow{2}{*}{$\begin{array}{c}\text { Neg. } 1: 4(-1) \\
\text { Pos. } 1: 4 \text { to } 1: 16(0) \\
\text { Pos. } 1: 32 \text { to } 1: 128 \\
(+1) \quad \ldots\end{array}$} & $\begin{array}{l}3 \\
9\end{array}$ & $\begin{array}{r}5 \\
10\end{array}$ & $\begin{array}{l}3 \\
4\end{array}$ \\
\hline & & 3 & 5 & 1 \\
\hline
\end{tabular}

Cats, Dogs, and Pet Food.-The results given in Table III show that ownership of a dog or cat was associated with a relatively high range of dye test titres. When the results for husbands and wives were examined separately it was found that those husbands who handled pet food had a particularly high proportion of above-average titres. This contrasts with the results for the wives handling pet food; their titres were not significantly greater than wives who did not handle pet food (Table IV). Further breakdown of the husbands' titres as between the handling of cat food and dog food showed higher titres in those handling cat food than in those handling dog food (Table V).

Raw Meat for Human Consumption.-Naturally all the wives handled uncooked meat for human consumption, but when the husbands who handled it were compared with those not handling it no difference was found in antibody levels (Table VI). None of the men in the study was a butcher or worked in a slaughter-house.

TABLE III.-Toxoplasma Titres, Husband and Wife Together, According to Presence or Absence of Dog or Cat at Time of Test

\begin{tabular}{|c|c|c|c|c|c|}
\hline & Code: & -1 & 0 & +1 & Total \\
\hline \multirow[t]{2}{*}{$\begin{array}{l}\text { Dog or cat } \\
\text { No dog or cat }\end{array}$} & $\because$ & $\begin{array}{r}6 \\
20 \\
\end{array}$ & $\begin{array}{l}20 \\
23\end{array}$ & $\begin{array}{r}10 \\
7\end{array}$ & $\begin{array}{l}36 \\
50\end{array} \begin{array}{l}F=6.1808 \\
0.025>P>0.01\end{array}$ \\
\hline & & 26 & 43 & 17 & 86 \\
\hline
\end{tabular}

TABLE IV.-Toxoplasma Titres of Husbands and Wives According to Whether They Handle Dog and/or Cat Food

\begin{tabular}{|c|c|c|c|c|}
\hline Code: & -1 & 0 & +1 & Total \\
\hline $\begin{array}{l}\text { Husband handles } \\
\text { Husband does not handle }\end{array}$ & $\begin{array}{l}2 \\
9\end{array}$ & $\begin{array}{r}7 \\
16\end{array}$ & $\begin{array}{l}7 \\
2\end{array}$ & \begin{tabular}{l|l}
$16=8.1007$ \\
27 & $\begin{array}{l}F=01>P>0.001\end{array}$
\end{tabular} \\
\hline Total . & 11 & 23 & 9 & 43 \\
\hline $\begin{array}{l}\text { Wife handles } \\
\text { Wife does not handle } \ldots\end{array}$ & $\begin{array}{l}9 \\
6\end{array}$ & $\begin{array}{r}12 \\
8\end{array}$ & $\frac{3}{5}$ & $\begin{array}{l:l}24 & F=0.7897 \\
19 & P>0.05\end{array}$ \\
\hline Total & 15 & 20 & 8 & 43 \\
\hline
\end{tabular}

TABLE V.-Toxoplasma Titres of Husbands According to Whether They
Handle Cat/Dog Food

\begin{tabular}{|c|c|c|c|c|c|}
\hline Code: & -1 & 0 & +1 & To & \\
\hline \multirow{2}{*}{$\begin{array}{l}\text { Husband handles cat food } \\
\text { Husband does not handle } \\
\text { cat food }\end{array}$} & 1 & 6 & 5 & $12)$ & $F=5.6249$ \\
\hline & 10 & 17 & 4 & $31)$ & $0.025>\mathrm{P}>0.01$ \\
\hline \multirow{2}{*}{$\begin{array}{l}\text { Husband handles dog food } \\
\text { Husband does not handle } \\
\text { dog food }\end{array}$} & 1 & 5 & 4 & 10) & $\mathrm{F}=3.4972$ \\
\hline & 10 & 18 & 5 & 33) & $P>0.05$ \\
\hline
\end{tabular}

TABLE VI.-Toxoplasma Titres of Husbands According to Whether They Handle Uncooked Meat for Human Consumption or Not

\begin{tabular}{l|c|c|c|c}
\hline Code: & -1 & 0 & +1 & Total \\
\hline $\begin{array}{l}\text { Husband handles } \\
\text { Husband does not handie }\end{array}$ & 5 & 9 & 6 & $21, \begin{array}{l}\mathrm{F}=0.1837 \\
\mathrm{P}>0.05\end{array}$ \\
\hline
\end{tabular}

Kitchen Cleanliness.-The level of cleanliness of the kitchen over the whole series bore no relation to antibody level, but when lack of cleanliness was associated with handling of pet food a highly significant $F$ ratio of 8.9624 resulted, again only for the men (Table VII).

TABLE VII.-Toxoplasma Titres of Husbands and Wives According to

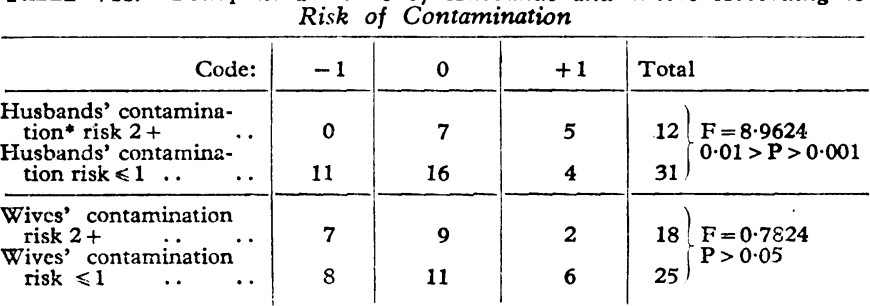
Contamination risk score was calculated by scoring 0 for a clean, 1 for an average,
and 2 for an unclean kitchen and adding one point for handling dog food and one point for handling cat food, giving a range of score $0-4$.

Other Variables.-No significant correlation was found with other variables, including contact with pet rabbits, pet mice, budgerigars, goldfish, wild mice and rats, the "worming" of pets, flea infestation, service or holidays abroad, gardening, and salad eating.

\section{Discussion}

In this area cats are fed mainly on the lungs, spleen, liver, and heart of sheep, pigs, and cattle. Dogs are fed mainly on liver and meat scraps. Well-sterilized canned meat is also used to feed dogs and cats. 
The present results suggest that men in the survey with higher than average titres may have been infected through contact with the lungs, livers, hearts, and spleens of sheep, pigs, and cattle. A second possibility is that the dogs and cats became infected by ingesting the toxoplasma organisms from their food and in turn infected their owners through their faeces. Toxacara cati may carry toxoplasma cysts (Hutchinson, 1967), and this is a form of faecal transfer which must be considered. Few of the husbands and wives had ever treated their cats for worms, and a history of "worming" dogs had no effect on the toxoplasma dye test titres in the survey; but this, of course, does not rule the possibility out. A third alternative is that the dye test titre may rise in response to ingestion of dead toxoplasma organisms by persons infected earlier in life. The limitation of the strong correlation to the men, however, suggests a more specific response. A fourth suggestion that they could be contaminated by infected pet saliva when feeding their animals is made less likely by the results of a survey of cat and dog bites in the same practice. No rise in titre was found one month after the bite in 19 people bitten by dogs and one bitten by a cat.

When all the variables are taken into account the significant findings are the high dye test titres in both husbands and wives who owned cats and dogs at the time of the investigation, and particularly the high titres in the husbands who handled pet food in less than clean surroundings. It is suggested that the higher level of antibody in this group of men could be due to handling infected raw lungs, liver, and tissues used for pet food. The wives' higher titres appear to have been gained in a different way, and they may have been infected at earlier ages than their husbands. Further studies of different age groups would be needed to find out how and when their infections were acquired.

It is important to remark that these results relate only to a selected group of people in one particular urban area. Toxoplasma dye test titres are known to display different patterns in different areas. Nevertheless, the present method of study may prove useful in other surveys.

I should like to thank Professor E. G. Knox, of the Department of Social Medicine, University of Birmingham; Dr. W. Kwantes and the staff of the Public Health Laboratory, Swansea; Dr. K. Cross and the Royal College of General Practitioners' Records and Research Unit; and Mr. R. Crow for help in this study; also Dr. J. C. Siim, Dr. J. K. A. Beverley, and Dr. D. G. Fleck for helpful discussions.

\section{REFERENCES}

Beverley, J. K. A. (1960). In Recent Advances in Clinical Pathology, 3rd ed., edited by S. C. Dyke, p. 38 . Orford, Churchill.

Beverley, J. K. A., and Beattie, C. P. (1958), Lancet, 2, 379.

Fletcher, S. (1965). Fournal of Clinical Pathology, 18, 193.

Hemsath, -F. A., and Pinkerton, H. (1956). American Fournal of Clinical Pathology, 26, 36.

Hutchinson, W. M. (1967). Transactions of the Royal Society of Tropical Medicine and Hygiene, 61, 80.

Kass, E. H., Andrus, S. B., Adams, R. D., Turner, F. C., and Feldman, H. A. (1952). Archives of Internal Medicine, 89, 759.

British Medical fournal, 1968, 2, 5 .

Sabin, A. B., and Feldman H. A. (1948). Science, 108, 660.

\title{
A 60\% Oxygen Supply for Medical Use
}

\author{
J. E. COTES,* D.M., F.R.C.P. ; A. G. DOUGLAS-JONES, †; M. J. SAUNDERS $\ddagger$
}

\begin{abstract}
Summary : A supply of $60 \%$ oxygen with $40 \%$ nitrogen $\$$ should be acceptable for most clinical purposes, since usually only low dosages of oxygen are required. The gas may be provided by means of an oxygen concentrator (Rimer-Birlec), which is a compact, transportable, electrically operated apparatus capable of providing $28 \mathrm{l} . / \mathrm{min}$. ( $1 \mathrm{cu}$. ft./min.) of $60 \%$ oxygen from a source of compressed air. The biological effect of the gas from the device is the same as that of $60 \%$ oxygen from a conventional source. Measurements of inspired oxygen concentration show that the $60 \%$ oxygen may be used with present-day oxygen masks to provide inspired oxygen concentrations in the range 25 to $40 \%$; for higher inspired concentrations alternative equipment is likely to be required. The concentrator appears to be a practical source of oxygen for expeditions and out-of-the-way places. It may provide an economical supply for a ward block, and with further development should be a convenient source of $30 \%$ oxygen for domiciliary use.
\end{abstract}

\section{Case for $60 \%$ Oxygen}

Oxygen for use in hospitals is normally supplied as $100 \%$ "pure" gas. The majority of applications in general medicine, surgery, and paediatrics, however, are for 25 to $40 \%$ oxygen (British Medical fournal, 1967), while the prolonged use of concentrations in excess of $60 \%$ invariably carries an increased risk from oxygen toxicity (Welch et al., 1963 ; Nash et al., 1967). In addition, in relation to anaesthesia, as for subjects exposed to acceleration, the use of $100 \%$ oxygen may give rise to atelectasis. In the case of aviation this hazard may be overcome by the routine use of a 40 to $60 \%$ oxygen: nitrogen mixture which is switched to $100 \%$ oxygen only in the event of failure of cabin pressurization (Ernsting, 1965).

There would seem to be a strong case for a similar provision in anaesthesia. In this event the requirement for $100 \%$ oxygen is confined to a relatively small number of patients with circulatory collapse and pulmonary arteriovenous shunting, also to patients with acute carbon monoxide poisoning and others who may require hyperbaric oxygen therapy (see, for example, Cotes, 1968). Ideally, these patients should be treated in an intensive care unit where $100 \%$ oxygen would be available. The likelihood that such patients will continue to require treatment in general wards should not, however, inhibit consideration of possible local production of a $60 \%$ oxygen: nitrogen mixture by removal of nitrogen from air. For oxygen in out-of-the-way places or where there is a relatively constant demand the cost is usually less than that for an equivalent volume of oxygen supplied in the conventional manner. The equipment for production of $60 \%$ oxygen is now available commercially (Cooper, 1968).

* Member of Scientific Staff.

† Apprentice Technician.

‡ Apprentice Technical Officer.

Pneumoconiosis Research Unit of the Medical Research Councll, Llandough Hospital, Penarth, Glamorgan. 